\title{
Towards a comprehensive framework for evaluating sustainable development in new Egyptian cities using GIS as a tool
}

\author{
Hassan Hilmi ${ }^{\mathrm{a}}$, Marwa Adel El-Sayed ${ }^{\mathrm{b}}$. \\ ${ }^{a}$ Student at the British University in Egypt (BUE), Address, Faculty of Engineering, \\ Architectural Engineering Department, El Sherouk City, Egypt \\ ${ }^{b}$ Associate Professor at the British University in Egypt (BUE), Address, Faculty of \\ Engineering, Architectural Engineering Department, El Sherouk City, Egypt
}

\begin{abstract}
1. Abstract:
The process of urban development is becoming more difficult because of the growing challenges that face the urban developers and negatively interfering with their success. For example, the shortage of resources, the environmental emissions that are responsible for environmental pollution, and the difficulty to deal with the effects that take place because of the climate change. Hence, urban planners are taking decisive actions to encourage the development of sustainable cities where they will be able to meet the economic, social and ecological challenges. Urban Planners and developers should evaluate the performance of a sustainable city. Life-cycle analysis (LCA), input-output analysis (IOA), carbon footprint (CF), ecological footprint (EF), ), cost benefit analysis (CBA) and Emergy Analysis (EA) are

six methods used by planners to conduct such evaluation, but each one is used individually. This paper aims to set calculation criteria for the for mentioned evaluation methods based on Geographic information system (GIS) as advanced tool to set a pilot method that could be applied by planners for evaluating sustainable city development. The result sets an integrated scientific framework for the six evaluation methods divided into three main phases inclusive planning phase, towards low carbon phase, and final decision-making phase. The first phase considers the following evaluation methods EF, EA, CBA, IOA, and LCA. The second phase uses the following evaluation methods CF, IOA, and LCA. Finally, the third phase integrates the following evaluation methods $\mathrm{CBA}, \mathrm{CF}, \mathrm{EF}, \mathrm{EA}$.
\end{abstract}

Keywords: Sustainable City-Sustainable Development-Evaluation MethodsIntegration- GIS.

\section{Introduction}

Cities are one of the most consuming factors of resources and producing of waste, especially in transportation and building system (The World Bank, 2010). Concurrently, the process of urban development is becoming more difficult, because of the challenges that are facing the urban developers and planners (Dong, et al., 2016, Vera, Mels, Keesman, Rijnaarts, \& Huub, 2011). In these conditions, it is crucial to find a solution for the consuming cities to make it adapt with the nature, environment and deal no harm, leading to an approach called the sustainable city. One of the pioneers who adopted the concept of sustainable cities is Richard Register in 1975. He drew attention to "rebuilding cities in balance with nature" (Register, 1987). The process of urban development for sustainable city is complex (Baynes, 2009). Hence, there is no certain evaluation method was able to fully assess the overall performance of one city (Dong, et al., 2016), as all the evaluation methods are being used individualy. Thus, the main aim of this paper is to provide an extensive literature review on the six well-known evaluation methods, through adopting a multicriteria mixed approach methodology. The 
evaluation methods are as follows: life-cycle analysis (LCA), input-output analysis (IOA), carbon footprint $(\mathrm{CF})$, ecological footprint $(\mathrm{EF})$, cost benefit analysis (CBA) and Emergy Analysis (EA) (H. Dong et al., 2016).

Both qualitative and quantitative data are used to propose an integrated scientific framework criteria based on using GIS as a tool proposed for planners (Pedro, Silva, \& Pinheiro, 2019) to measure and evaluate the overall performance of the sustainable city, and identify its key problems, to ease the complex process of urbandevelopment.

\section{Overview of sustainable city}

Even though the concept of sustainable city was proposed a long time ago, it was only throughout the past fifteen years planners implemented the concept of sustainable city claiming that these are the sustainable city times (Register, 2009). A large number of macro-scale developments are attempting to implement the sustainable city concept (Z. Lin, 2018). The term "sustainable city" defined as an ecologically friendly city that allows its inhabitants to live a fulfilling quality of life without neglecting the side effects that are harmful for the environment. In 1970 Arcosanti; an experimental town in Phoenix, Arizona was going to be built in the United states by the Cosanti Foundation (Lian Koh Asanga Gunawansa Lovleen Bhullar, 2010). It planned to be the first model of a sustainable city. However, the experiment took place while the global warming issue and ecological greenhouse gas emissions were not identified. Hence, neither the public nor the financial organizations supported the implementation of the town experiment. (Grierson, 2016).

\subsection{The Rise of Sustainable City Movement}

Regardless of the fact that cities are certainly humanity's greatest inventions (Stoltz, Shafqat, Arias, \& Lundqvist, 2014). The impact of the design, construction and operation of cities is devastating for the environment (Newman, 2006). The definition of cities is not limited to houses that people use to live in, they undoubtedly play a major role in the rapid increase of the global urbanization, and a study showed that urban areas are housing nearly more than $50 \%$ of the global population with a rate of growth reaching $1.85 \%$ every year (Bocquier, 2005)
As a result, cities are devastating for the global energy system and they will have a great impact on the future global energy system (Stoltz et al., 2014). For the response of the impact of cities in the global energy system, planners started to find the best method to use to evaluate the development of sustainable cities (Pedro et al., 2019). There are three main terms that are essential to establish a sustainable urban development: the synchronized pursuit of economic wealth, environmental quality and social justice (Purvis, Mao, \& Robinson, 2018). Researches suppose that justice should not be limited to one generation, as it is believed to be the heart of sustainability, it should also consider the environmental, economic and social equity between future generations (L. Liu, 2018). Sustainability will not be achieved unless justice is (L. Liu, 2018).

Since the development of sustainable city concept has been carried out by sir Register in his book "building cities with balance with nature" (R Register, 2002), there has been a constant improvement by the urban planners. John Blewitt in his book "Understanding Sustainable Development" Claims that sustainable city development is "a whole systems approach integrating ecologically efficient industry, administration, aspirations, people's needs, landscapes and harmonious culture, where agriculture, nature and the built environment are functionally integrated." (Blewitt, 2008). Nevertheless, the definition of sustainable city development and its evaluation methods is controversial since there is still no certain definition of what a sustainable city is? and how to evaluate the performance of it? (Datta, 2012; Joss, Cowley, \& Tomozeiu, 2013). Moreover, there are a lot of conflicts and confronts that are attempting to achieve the 
urban sustainability under the mantle of sustainable city construction in China (Pow \& Neo, 2013). According to Liu the definition of sustainable city identifies the sustainable cities as "urban areas that have purposely studied and applied a plan that seeks to enhance the city's environmental development while taking into consideration social and economic developments." (L. Liu, 2018).

\section{A comprehensive review on evaluation methods}

There is still no precise definition or explanations of what a sustainable city is, or how to evaluate and tell if a sustainable city is working well (de Jong, Wang, \& Yu, 2013). The research will illustrate the strengths, weaknesses and key problems for each evaluation method (IOA), (LCA), (EF), (CF), (EA) and (CBA).

\subsection{Input-output analysis (IOA) method}

This method was first proposed by Leontief in the 1930s, it is a top-down economic technique done by using the sectoral monetary transaction data to measure the relationship between different economic divisions (Leontief, 1970, pp. 262-271). The (IOA) also helps in studying environmental problems by providing appealing features that could also be used for the assessment of different incarnated capital, such as incarnated energy (Baral \& Bakshi, 2010), incarnated/virtual water (H. Dong, Geng, et al., 2014) and incarnated carbon releases (L. Dong et al., 2013; Jiang, Cai, Wan, \& Wang, 2015). First, a full regional and inter-regional supply chain description is provided by the (IOA) method, considering preventing the error of truncation that is normally found while using the bottom-up approaches (Feng, Chapagain, Suh, Pfister, \& Klaus, 2011). Second, the environmental problems designated by the (IOA) method and it comes to a final consumption instead of the intermediate consumption, making it possible to evaluate direct as well as indirect effects from the perspective of consumption. Nevertheless, this method further applied at macrolevels, such as regional or national levels, rather than microlevels, such as individual products or industrial parks, because of the shortage of Input-output tables.

(IOA) method was commonly used for carbon footprint, ecological footprint, emergy and water footprint. For example, there was a regional water shortage problem in Beijing, and to alleviate the effects of this problem a water footprint study was done by the (IOA) method.(Feng et al., 2011; Z. Wang, Huang, Yang, \& Yu, 2013). The use of the (IOA) method recommended Coordinating interregional trade closely to help enhance the regional water resource consumption. Related studies were accomplished in other territories that suffered from water shortage, such as Liaoning a Chinese State (H. Dong et al., 2012). In 2009 Tonooka and Kanemoto Applied a multi-regional input-output model (MRIO) to measure the Carbon dioxide releases incarnated in the international trade in Japan and concluded that releases incarnated in imports to japan expanded substantially (Kulionis, 2014). Likewise, in 2004 Jackson and Druckman examined the carbon footprint of UK houses employing a virtual MRIO model and noticed that more than one fourth of Carbon dioxide releases in a standard UK house were because of recreation and leisure areas (Druckman \& Jackson, 2009). Similarly, Giljum and Hubacek also used (IOA) for ecological footprint study and determined indirect and direct land constraints to produce exports from the fifteen countries of the European Union to the rest of the world (Klaus \& Giljum, 2003).

\subsection{Lifecycle analysis (LCA) method}

This evaluation method is used to carefully and fully evaluate the effect of product choices 
on the natural environment, from the raw materials generation process to the wastes disposal process, and accordingly making it possible to decide the most appropriate and least-damaging choice of materials (EEA, 2002; Francis, 2003). The (LCA) was first proposed between the late 1960s and early 1970s (Bengtsson, 2011). The first quantitative LCA study was first done for the Coca-Cola company in 1969, it was done by collecting statistical information about the requirements for resources, loads of emissions, and flows of waste of different Coca-Cola bottles.

From then on, LCA has been commonly used to assess the impact of dealing and discarding of wastes on environment, such as food recycle.(Cellura, Ardente, \& Longo, 2012), waste paper recycle (Liang, Zhang, \& Xu, 2012; L. Wang, Templer, \& Murphy, 2012), waste glass recycles (Blengini et al., 2012), Waste-toEnergy approach (Tunesi, 2010; VázquezRowe, Marvuglia, Rege, \& Benetto, 2014) and PET bottle recycle (Song \& Hyun, 1999). LCA has also been implemented in researches on supply reprocessing procedure and sustainable cities. For example, a study was done on agrochemical complex contained thirteen petrochemical and chemical productions in the Mississippi, USA by performing an input to output life cycle evaluation analysis (LCA) they found that LCA is an exceptionally valuable implement for the analysis and comparisons of diverse proposals of manufacturing ecosystems (Singh, Lou, Yaws, Hopper, \& Pike, 2007).

Chen, Xi, Geng and Fujita applied and modified the LCA evaluation method on their attempt to evaluate the potential ecological gains, comprising the decrease of GHG emissions and conserving fossil fuels by using a variety of plastics recycling technologies established by Japanese developers in Shenyang, China. (Chen, Xi, Geng, \& Fujita, 2011). Hence, the LCA evaluation method is unlike the IOA method, it is mainly applied at smaller scales such as a product or a procedure in which the availability of data is present.

\subsection{Ecological footprint (EF) analysis}

Rees and Wackernagel first established the concept of (EF) in the 1990s, in their attempt to estimate the organically fertile land and water that is required for a certain amount of people to achieve the equilibrium state of the consumption and production process. As well as taking in a small amount of the waste produced by fossil and the consumption of nuclear fuel (Bazan, 1997; Rees, 1992; Wackernagel et al., 2002). Ecological footprint analysis mainly divides the city sectors to six bio productive areas: use of fertile land, use of forest lands, use of pastureland, use of productive sea space, use of built-up land, and use of forest land (Hoekstra, 2007).

Ecological footprint analysis is commonly used for assessing the environmental sustainability by comparing it to the population size, which is characterized as "the ability of an ecosystem to produce useful biological materials and absorb carbon dioxide emissions." (Geng et al., 2014). If Ecological footprint is larger than ecological carrying ability, it means that individual actions have exceeded the nature's maximum capability which the environment could manage, showing a sign of unsustainable development environment.

Ecological footprint evaluation method is a budget efficient tool and can be employed to various scales, especially for states and towns. For example, a study showed that London's ecological footprint in 1995 was 125 times larger than the size of the city itself. This shows that London to properly work, it needed an area nearly of the size of UK's largest viable land area, to be able to give all the resources the city utilizes and to get rid of its contaminants and wastes (Wackernagel, Kitzes, Moran, Goldfinger, \& Thomas, 2006). In addition, in 2014 a study was done that made a comparison between the ecological footprints of a city in a country under the developing process and a city in a settled and already established country. This study showed quick ecological footprint expansions in cities in countries under the developing process, and unlikely the ecological footprint of the cities in established countries 
was comparatively stable. These findings show that more cooperation and support between cities at different stage of development is needed. And it can be provided by capacity building efforts and technology transfer (Geng et al., 2014).

\subsection{Carbon footprint (CF) analysis}

$\mathrm{CF}$ originates from the idea of ecological footprint, its popularity set off since 2007 with the aim of responding to universal warming. It is basically "the amount of $\mathrm{Co} 2$ equivalent emissions caused directly and indirectly by an activity." (Wiedmann \& Minx, 2008). Carbon footprint studies were performed at several ranges, such as countries, towns, homes, companies, manufacture processes and goods (H. Dong et al., 2016). It can be broken down into three categories, first, IPCC which is known as the Intergovernmental Panel on Climate Change method, input-output analysis (IOA) method and lifecycle analysis method (LCA). The use of LCA method is focusing on smaller scales such as corporations and manufactured goods, while IOA and IPCC methods are focusing on assessing provincial and town scale carbon footprints (H. Dong et al., 2016).

Several researches on territorial and town levels have been done. For instance, greenhouse gas secretions linked to the ultimate consumption of products, Hertwich, and peters measured facilities for 73 states and 14 world districts. In addition with the use of multiregional input-output (MRIO) model, they were able to recognize that national average for each individual footprints differ from $1 \mathrm{tCO} e \mathrm{e} / \mathrm{year}$ in African countries while being $30 \mathrm{t} / \mathrm{year}$ in the United States and Luxembourg (Hertwich \& Peters, 2009). A comparison of carbon footprints in 12 urban areas was proposed by Sovacool and Brown in 2010 (Sovacool \& Brown, 2010). In 2011 a study on the carbon footprint was done in Shenyang, China by using the IPCC method (Xi et al., 2011). In 2013, Lin studied the carbon footprint in Xiamen, China employing a hybrid method included the integration of both EIOA method and IPCC method (Jianyi, Liu, Meng, Cui, \& Xu, 2015).

\subsection{Emergy analysis method (EA)}

This method was initially offered by Odum in the late 1980s, it is basically "the total available energy of one kind previously required directly and indirectly through input pathways to make a product or service." (Odum, 1988, 1995). "The quantity of previous work undertaken by natural processes to regenerate or produce it" is signified as the emergy value of a resource (Odum, 2000; Tilley \& Swank, 2003). Consequently, emergy has the benefit of being able to designate principles to investments and nature's environmental efforts, for example: deep geothermal heat, solar and gravity, to make and assist flows, supplies, and services and to make a contribution for the financial scheme (Geng, Sarkis, Ulgiati, \& Zhang, 2013). Emergy helps in offering an integrated quantitative process for enumerating the comparative amount of energy flows and raw material in the financial system and in the ecosystem (Campbell, Lu, \& Lin, 2014) because it converts all sorts of results if it was man-made or natural goods to solarcomparable Joules.

Decision makers and planners should raise the correct urban development policies by using the useful perceptions offered by Emergy analysis (Li \& Wang, 2009). hence, many researches have been accomplished, such as sustainable level evaluation (Lei \& Wang, 2008), urban metabolism (Huang \& Chen, 2005; Huang, Lee, \& Chen, 2006; Sun et al., 2015; Zhang, Yang, Liu, \& Yu, 2011), urban land use (Huang, Lai, \& Lee, 2001) and urban ecosystem health assessment (G. Y. Liu et al., 2009; Vassallo, Paoli, Bazzurro, Masciulli, \& Fabiano, 2006). Furthermore, for planners to quantify different environment performance, the unique emergy assessment signs can be utilized. For example, emergy rate of return can signify the utilization of local resources from human activities, and emergy rate of loadings can calculate the pressure of individual actions on local environment resultant from the overabundant mistreatment of investment or nonrenewable resources from outside (Geng, Zhang, Ulgiati, \& Sarkis, 2010). Emergy 
sustainability index helps signify the feasibility level of the district or town.

\subsection{Cost benefit analysis (CBA)}

Conventional Cost-Benefit Analysis (CBA) is "a systematic process used to calculate and compare benefits and costs of a project, decision or government policy." (Melichar, Šcasnl'y, Hunt, \& Navrud, 2009; D. Pearce, Atkinson, \& Mourato, 2006). Regarding the environmental and sustainable development concerns, this method measures the damages on individuals healthiness and environment resulting from financial events and try to reduce them by finding the most efficient ways, along with comparing the cost of ecological impairment to the cost of alleviation (Bachmann \& Kamp, 2014; Hanley, 2013). Particularly, the

\section{Using Geographic Information System to set a pilot method}

Planners are facing so many challenges to improve the evaluation of sustainable development of new cities (Datta, 2012; Joss et al., 2013). Hence, this evaluation requires to be carried out using new techniques of urban planning tools to overcome the difficulty of measuring and assessing the development of new cities (Pedro et al., 2019). Geographic Information System (GIS) could be used as a multi-criteria decision support tool (MCDS) (El- externality of the environment

(Bickel, Friedrich, \& others, 2004), and social welfare (D. W. Pearce et al., 1996) are taken into account in the cost-benefit estimation.

Numerous CBA techniques have been utilized to monetize the externality of the environment, for example External A (Bickel et al., 2004) ready to afford the payment, and estimate the cost of the life cycle. In order to lower the externality of the environment, systematical methods such as circular economy have been suggested by ecological economists (D. W. Pearce \& Turner, 1990) and extensively employed in Japan, Germany and China (Geng, Zhu, Doberstein, \& Fujita, 2008; OECD, 2009). Nevertheless, as the mainstay of CBA is to monetization, hence, it is limited to quantifying some ecological value, ecosystem value and social gain. (Kolosz \& Grant-Muller, 2015; Massiani, 2015; Söderqvist et al., 2015)

Sayed, Mahmoud, \& El-Barmelgy, 2015). This will accordingly help with the integration of the evaluation methods for a final appropriate planning decision. To avoid using each evaluation method individually in the assessment, the method is based on (GIS) as a tool to achieve the precise integrated evaluation of sustainable urban development.

\section{Research Method}

The research sets a pilot method using GIS to calculate the implications of six evaluation methods. These methods are as follows, (IOA), (LCA), (EF), Emergy Analysis, (CF), and (CBA).

\subsection{IOA and LCA methods}

Since IOA and LCA are considered as tool for data collection, accordingly all the collected data should be converted into the suitable format to be populated in the GIS in the form of feature class grouped into different feature datasets. After populating the data in GIS, it is now considered as geospatial data that can be either raster or vector.
Both IOA and LCA used qualitative and quantitative data that are essential in decision making and spatial modeling. Using GIS will set a rational and precise database that can be used and updated.

\subsection{Ecological Footprint:}

The calculations of the ecological footprint are divided into two parts. First, calculating the biocapacity of the city bio productive areas and then, comparing it to the actual ecological footprint. This applied through converting their units from unweighted hectares to standardized global hectares using the yield and equivalence factors. 
First, calculations of the Biocapacity of the city will be conducted through using GIS Model Builder. The Model Builder is considered as programming language used for geoprocessing workflows to document the both data calculations factors and spatial analysis data. Achieving a GIS Model Builder is applied firstly by using dataset, maps, equivalence factors and yield factors. Then adding each feature class in its designed workspace. Followed by visualizing the applied calculations in a sequenced diagram.
Finally running the model builder using Python scripting language. The calculations will be applied on six bio productive city sectors as follows; Croplands, Forest Lands, Fisheries areas, Pasture Lands, Built up areas, Sequestration areas or energy biomass accumulation areas. The equations used for calculation are shown in the following figure.

The following table shows the equivalence and yield factors of different city bio Productive areas:

Table 2 Peruvian Yield Factors (2001), (Wackernagel et al., 2005)

\begin{tabular}{|r|r|r|}
\hline Bio productive Area & Equivalence Factor [gha/ha] & Yield Factor [-] \\
\hline Croplands & 2.19 & 0.98 \\
\hline Forest Lands & 1.37 & 0.82 \\
\hline Pasture Lands & 0.48 & 1.81 \\
\hline Built-up area & 2.19 & 0.98 \\
\hline Inland Water & 0.36 & 2.96 \\
\hline Marine & 0.36 & 3.39 \\
\hline
\end{tabular}

Second, the calculation of the ecological footprint, the calculations are done using the footprint calculator which developed by Global Footprint Network that allows to calculate the footprint for each capita. The results are multiplied by the number of people living in the city to attain the total ecological footprint of the city, it also shows how many earths are going to be needed if everyone on earth had similar footprint of the calculated ones. https://www.footprintcalculator.org/

\subsection{Cost Benefit Analysis}

CBA on the Macro-Scale is required to be performed on a combination of projects to have a total cost-benefit analysis of a unified program. This could be carried out by employing the "with and without" tactic to each project, or to a group of projects using two sequenced techniques in GIS. The first technique is the Model Builder techniques to calculate the cost, then followed by Create New Report technique to perform comparison reports. These criteria compare between the data extracted from the Model builder which represent the cost and the data that populated in the report structure and represent the benefit.

CBA on the micro scale is to identify if the project revenue more than the projected cost. The formula of calculating the cost feasibility will be the Net Present Value, as it considers the discounting variables for more accurate ratio (Leonard, 2018).

$$
\mathrm{NPV}=\text { Value }(\mathbf{1 + r})^{\wedge} \mathrm{t}
$$

NPV is the net present value that will be used in the cost benefit ratio equation. Value is the benefits of the project, $(r)$ is the discount rate, $(\mathrm{t})$ : is the time frame of the project. If the $\mathrm{NPV}>0$, then the project is worth the money invested, and if the NPV $<0$, then the project is losing money. This equation will be applied by using the GIS Model Builder.

\subsection{Carbon Footprint}

The city is divided into different sectors that are responsible for $\mathrm{Co} 2$ emission; these sectors are as follows; ground-based transportation, different building uses along the city, industrial zones, and rest of city land uses. The GIS Model Builder will be used to apply the 
equation of calculating the carbon footprint of each sector as follows:

\subsubsection{Ground-based transportation}

The ground-based transportation emissions are divided according to the vehicles type and size as follows: petrol and diesel cars, regular taxi Cairo cap, petrol and diesel vans, local buses and coaches, motorcycles and railways (El-Sayed et al., 2015). To calculate Co2 emitted from petrol or diesel cars, or vans, or motorcycles: $\mathrm{CO} 2$ emission = G.CO2 per Km * Length of Street in $\mathrm{Km} *$ Number of (petrol or diesel cars, or vans, or motorcycles). To calculate $\mathrm{Co} 2$ emitted from taxis, buses or railway: $\mathrm{CO} 2$ emission $=\mathrm{G} . \mathrm{CO} 2$ per passenger $\mathrm{km} *$ Length of Street in $\mathrm{Km} *$ Average passenger occupancy * Number of (taxis, or trips, or buses).

\subsubsection{Different building uses along the city}

It is required to calculate the $\mathrm{CO} 2$

emission according to the area and different uses of the Buildings such as (residential, administrative, hospitals, commercial, cultural, education and entertainment).

\subsubsection{Industrial Zones along the city}

It is essential to calculate the $\mathrm{CO} 2$ emission according to the type of industry employed by the factory such as (agriculture and livestock products, food processing, beverages and tobacco, Wood products, building materials, chemicals, metals, manufacturing and repairing and maintenance centers), and number of factories, putting into consideration that the factories size and production are average

\subsubsection{Land Uses Along the City}

It is required to calculate the $\mathrm{CO} 2$

emission of the different land uses along the city such as (oxidation lakes, agriculture lands, forests, crusher and public dumps).

\section{Discussion and results}

There was no certain application of a former integration in previous studies. Previous proposal of an integration of five different evaluation methods on the macro scale was recommended, but it needed more research and required more potential application in new city projects. Also, there was an integration on the multi scale that aims to achieve a low carbon city using a hybrid method (H. Dong et al., 2016). Although it has been operated for quite a few studies for low carbon cities (H. Dong, Ohnishi, et al., 2014; L. Dong et al., 2013; Jianyi et al., 2015; J. Lin, Liu, Meng, Cui, \& Xu, 2013), but it still require to be more endorsed. Finally (H. Dong et al., 2016) proposed an integration of decision and environmental type methods on the micro scale that aims to help the decision makers to evaluate the economic feasibility of the development of the city by promoting the cost as a pivotal factor in the decision-making process. This type of integration has not been used or advertised. Therefore, it is necessary to introduce more advanced integration attempts that consider the economic cost feasibility of the environmental policies to encourage the transition towards sustainable city development.

The contribution of this study suggests a new technique to be used in the implication of the previously mentioned integrations, by setting a pilot method for the assessment using the GIS as a tool for calculating and applying the integration. The result conforms to a relevant study by (El-Sayed et al., 2015) that made an assessment of the carbon footprint of $10^{\text {th }}$ of Ramadhan city using the GIS model builder to apply the calculation formula.

\section{Conclusion}

The six evaluation methods could be integrated as shown in (figure 3.1) on three different phases. The first phase involves the use of five different evaluation methods (IOA, LCA, $\mathrm{EA}, \mathrm{EF}, \mathrm{CBA})$ on the macro scale and is called the inclusive planning phase it involves 
proposing recommendations on enhancing regional bio-capacity and sustainability by combining the Ecological Footprint and Emergy analysis methods, while using the CBA method to clarify the economic viability by considering the economic cost. Furthermore, to make the assessment more precise and rational, the use of LCA and IOA methods is required to provide technological and information support. This integration can systematically manage the new city planning process. The second phase (Evaluating Carbon Footprint from a life cycle point of view) includes proposing an integration of environmental and economic type methods (CF, IOA, LCA). The proper low-carbon strategies are mainly raised and provided by $\mathrm{CF}$ method. Nevertheless, it is essential to combine the use of LCA and IOA methods with the CF method, to be able to have organized assessment from a life cycle point of view, and to avoid the emissions transfer problems by tracing the boundaries of the supply chain. Finally, the third phase (Cost as a decisive factor) compromises four evaluation methods (CBA, CF, EF, EA) to evaluate the economic feasibility of the city development, by promoting the cost as a key factor in the decision-making process. Incidentally, it is required to integrate the $\mathrm{CF}, \mathrm{EF}$ and emergy analysis with CBA to quantify the consequent ecological benefits. GIS is used as a tool to set a pilot technique that can be used by urban planners to apply the integration and ease the process of evaluation.

Emergy analysis was excluded from the calculations due to the limitations of data.

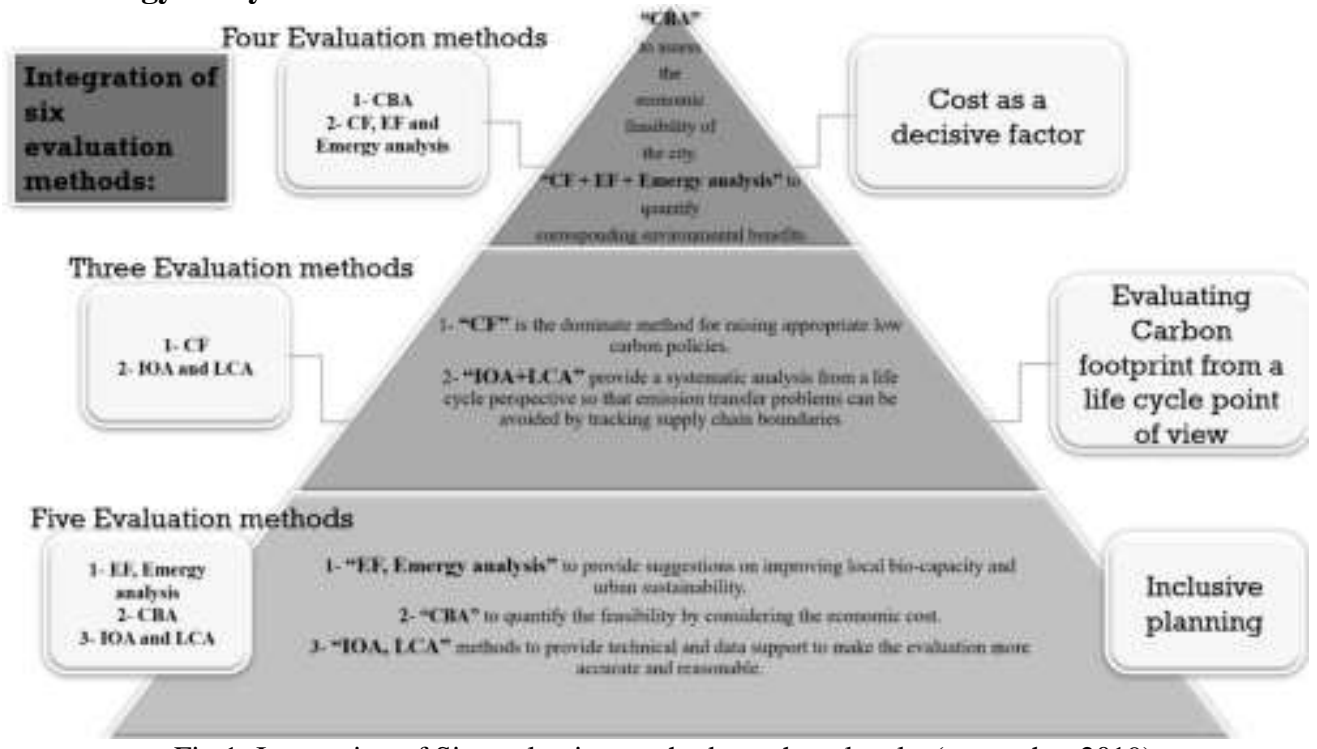

Fig 1: Integration of Six evaluation methods on three levels, (researcher,2019)

\section{Recommendations}

In response to Egypt's new vision of planning sustainable cities, it is recommended to use the above-mentioned integration as a tool to help planners fully identify the key problems of the city and easily evaluate its performance.
It is recommended to test the concluded pilot technique using one of the Egyptian new cities as a model. It is also advised that the chosen city belongs to the first or second generation of the Egyptian new cities. 


\section{References}

Bachmann, T., \& Kamp, J. (2014). Environmental cost-benefit analysis and the EU (European Union) Industrial Emissions Directive: Exploring the societal efficiency of a DeNOx retrofit at a coal-fired power plant. Energy, 68, 125-139. https://doi.org/10.1016/j.energy.2014.02.051

Baral, A., \& Bakshi, B. (2010). Emergy analysis using US economic input-output models with applications to life cycles of gasoline and corn ethanol. Ecological Modelling, 221, 18071818. https://doi.org/10.1016/j.ecolmodel.2010.04.010

Bengtsson, S. (2011). Life cycle assessment of present and future marine fuels. Report, (Cml), 57. Retrieved from http://publications.lib.chalmers.se/records/fulltext/148820.pdf\%5Cnhttp://ovidsp.ovid.com/ov idweb.cgi? $\mathrm{T}=\mathrm{JS} \& \mathrm{PAGE}=\mathrm{reference} \& \mathrm{D}=\mathrm{tspt} \& \mathrm{NEWS}=\mathrm{N} \& \mathrm{AN}=01448312$

Blengini, G. A., Busto, M., Fantoni, M., Fino, D., Blengini Gian Andrea, E. blengini@ polito. i., CNR-IGAG, I. of E. G., ... Fino Debora, E. debora. fino@polito. i. (2012). Eco-efficient waste glass recycling: Integrated waste management and green product development through LCA. Waste Management, 32(5), 1000-1008. https://doi.org/10.1016/j.wasman.2011.10.018

Campbell, D., Lu, H., \& Lin, B.-L. (2014). Emergy evaluations of the global biogeochemical cycles of six biologically active elements and two compounds. Ecological Modelling, 271, 32-51. https://doi.org/10.1016/j.ecolmodel.2013.01.013

Cellura, M., Ardente, F., \& Longo, S. (2012). From the LCA of food products to the environmental assessment of protected crops districts: A case-study in the south of Italy. Journal of Environmental Management, 93, 194-208. https://doi.org/10.1016/j.jenvman.2011.08.019

Chen, X., Xi, F., Geng, Y., \& Fujita, T. (2011). The potential environmental gains from recycling waste plastics: Simulation of transferring recycling and recovery technologies to Shenyang, China. Waste Management (New York, N.Y.), 31, 168-179. https://doi.org/10.1016/j.wasman.2010.08.010

Datta, A. (2012). India's Ecocity? Environment, Urbanisation, and Mobility in the Making of Lavasa. Environment and Planning C: Government and Policy, 30(6), 982-996. https://doi.org/10.1068/c1205j

de Jong, M., Wang, D., \& Yu, C. (2013). Exploring the Relevance of the Eco-City Concept in China: The Case of Shenzhen Sino-Dutch Low Carbon City. Journal of Urban Technology, 20(1), 95-113. https://doi.org/10.1080/10630732.2012.756202

Dong, H., Fujita, T., Geng, Y., Dong, L., Ohnishi, S., Sun, L., ... Fujii, M. (2016). A review on ecocity evaluation methods and highlights for integration. Ecological Indicators, 60, 1184-1191. https://doi.org/10.1016/j.ecolind.2015.08.044

Dong, H., Geng, Y., Fujita, T., Fujii, M., HAO, D., \& Yu, X. (2014). Uncovering regional disparity of China's water footprint and inter-provincial virtual water flows. The Science of the Total Environment, 500-501C, 120-130. https://doi.org/10.1016/j.scitotenv.2014.08.094

Dong, H., Geng, Y., Sarkis, J., Fujita, T., Okadera, T., \& Xue, B. (2012). Regional Water Footprint Evaluation in China: A Case of Liaoning. The Science of the Total Environment, 442C, 215224. https://doi.org/10.1016/j.scitotenv.2012.10.049

Dong, H., Ohnishi, S., Fujita, T., Geng, Y., Fujii, M., \& Dong, L. (2014). Achieving carbon emission reduction through industrial \& urban symbiosis: A case of Kawasaki. Energy, 64, 277-286. https://doi.org/https://doi.org/10.1016/j.energy.2013.11.005

Dong, L., Fujita, T., Zhang, H., Dai, M., Fujii, M., Ohnishi, S., .. Liu, Z. (2013). Promoting lowcarbon city through industrial symbiosis: A case in China by applying HPIMO model. Energy Policy, 61, 864-873. https://doi.org/10.1016/j.enpol.2013.06.084

Druckman, A., \& Jackson, T. (2009). The Carbon Footprint of UK Households 1990-2004: A Socio-Economically Disaggregated, Quasi-Multi-Regional Input-Output Model. Ecological 
Economics, 68, 2066-2077. https://doi.org/10.1016/j.ecolecon.2009.01.013

El-Sayed, M. A., Mahmoud, A. H. A., \& El-Barmelgy, I. M. (2015). Land Suitability Analysis for Urban Green Areas Using New Methods and Techniques. 276. Retrieved from https://www.amazon.com/Suitability-Analysis-Urban-GreenAreas/dp/3659410721/ref=sr_1_1?s=books\&ie=UTF8\&qid=1492514685\&sr=1$1 \&$ keywords=land+suitability+analysis+for+urban+green+areas

Feng, K., Chapagain, A., Suh, S., Pfister, S., \& Klaus, H. (2011). Comparison of bottom-up and topdown approaches to calculating the water footprint of nations. Economic Systems Research, 23. https://doi.org/10.1080/09535314.2011.638276

Geng, Y., Sarkis, J., Ulgiati, S., \& Zhang, P. (2013). Measuring China's Circular Economy. Science, 339, 1526-1527. https://doi.org/10.2307/41942068

Geng, Y., Zhang, L., Chen, X., Xue, B., Fujita, T., \& Dong, H. (2014). Urban ecological footprint analysis: A comparative study between Shenyang in China and Kawasaki in Japan. Journal of Cleaner Production, 75, 130-142. https://doi.org/10.1016/j.jclepro.2014.03.082

Geng, Y., Zhang, P., Ulgiati, S., \& Sarkis, J. (2010). Emergy analysis of an industrial park: The case of Dalian, China. The Science of the Total Environment, 408, 5273-5283. https://doi.org/10.1016/j.scitotenv.2010.07.081

Geng, Y., Zhu, Q., Doberstein, B., \& Fujita, T. (2008). Implementing China’s circular economy concept at the regional level: A review of progress in Dalian, China. Waste Management (New York, N.Y.), 29, 996-1002. https://doi.org/10.1016/j.wasman.2008.06.036

Grierson, D. (2016). Unfinished Business at the Urban Laboratory: Paolo Soleri, Arcology, and Arcosanti. Open House International, 41, 63.

Hanley, N. (2013). Environmental Cost-Benefit Analysis. In J. F. Shogren (Ed.), Encyclopedia of Energy, Natural Resource, and Environmental Economics (pp. 17-24). https://doi.org/https://doi.org/10.1016/B978-0-12-375067-9.00103-0

Hertwich, E., \& Peters, G. (2009). Carbon Footprint of Nations: A Global, Trade-Linked Analysis. Environmental Science \& Technology, 43, 6414-6420. https://doi.org/10.1021/es803496a

Hoekstra, A. (2007). Human appropriation of natural capital: Comparing ecological footprint and water footprint analysis. Ecological Economics, 68, 1963-1974. https://doi.org/10.1016/j.ecolecon.2008.06.021

Jiang, Y., Cai, W., Wan, L., \& Wang, C. (2015). An index decomposition analysis of China's interregional embodied carbon flows. Journal of Cleaner Production, 88, $289-296$. https://doi.org/10.1016/j.jclepro.2014.04.075

Jianyi, L., Liu, Y., Meng, F., Cui, S., \& Xu, L. (2015). Using hybrid method to evaluate carbon footprint of Xiamen City, China.

Kolosz, B., \& Grant-Muller, S. (2015). Extending cost-benefit analysis for the sustainability impact of inter-urban Intelligent Transport Systems. Environmental Impact Assessment Review, 50, 167-177. https://doi.org/https://doi.org/10.1016/j.eiar.2014.10.006

Kulionis, V. (2014). CO2 Emissions Embodied in International Trade of the UK. (May 2014), 1995-2009. Retrieved from http://lup.lub.lu.se/luur/download?func=downloadFile\&recordOId=4618953\&fileOId=46226 1

Leonard, K. (2018). How to Determine Whether the Cost-Benefit Ratio Is Positive or Negative | Chron.com. Retrieved February 18, 2020, from https://smallbusiness.chron.com/determinewhether-costbenefit-ratio-positive-negative-48312.html

Li, D., \& Wang, R. (2009). Hybrid Emergy-LCA (HEML) based metabolic evaluation of urban residential areas: The case of Beijing, China. Ecological Complexity, 6, 484-493. https://doi.org/10.1016/j.ecocom.2009.09.002

Lian Koh Asanga Gunawansa Lovleen Bhullar, K. (2010). \&quot;Eco-Cities\&quot; and 
\&quot;Sustainable Cities\&quot;-Whither? Retrieved from https://ink.library.smu.edu.sg/lien_research

Liang, S., Zhang, T., \& Xu, Y. (2012). Comparisons of four categories of waste recycling in China's paper industry based on physical input-output life-cycle assessment model. Waste Management, 32(3), 603-612. https://doi.org/https://doi.org/10.1016/j.wasman.2011.10.020

Lin, J., Liu, Y., Meng, F., Cui, S., \& Xu, L. (2013). Using hybrid method to evaluate carbon footprint of Xiamen City, China. Energy Policy, 58, 220-227. https://doi.org/https://doi.org/10.1016/j.enpol.2013.03.007

Liu, G. Y., Yang, Z. F., Chen, B., Zhang, Y., Zhang, L. X., Zhao, Y. W., \& Jiang, M. M. (2009). Emergy-based urban ecosystem health assessment: A case study of Baotou, China. Communications in Nonlinear Science and Numerical Simulation, 14(3), 972-981. https://doi.org/https://doi.org/10.1016/j.cnsns.2007.09.017

Liu, L. (2018). A sustainability index with attention to environmental justice for eco-city classification and assessment. Ecological Indicators, 85(October 2017), 904-914. https://doi.org/10.1016/j.ecolind.2017.11.038

Massiani, J. (2015). Cost-Benefit Analysis of policies for the development of electric vehicles in Germany: Methods and results. Transport Policy, 38, 19-26. https://doi.org/10.1016/j.tranpol.2014.10.005

Pedro, J., Silva, C., \& Pinheiro, M. (2019). Integrating GIS spatial dimension into BREEAM communities sustainability assessment to support urban planning policies, Lisbon case study. Land Use Policy, 83. https://doi.org/10.1016/j.landusepol.2019.02.003

Pow, C. P., \& Neo, H. (2013). Seeing Red Over Green: Contesting Urban Sustainabilities in China. Urban Studies, 50(11), 2256-2274. https://doi.org/10.1177/0042098013478239

Purvis, B., Mao, Y., \& Robinson, D. (2018). Three pillars of sustainability: in search of conceptual origins. Sustainability Science. https://doi.org/10.1007/s11625-018-0627-5

Register, Richard. (2009). Reflecting on Ecocity Times - Ecocity Builders. Retrieved November 30, 2019, from https://ecocitybuilders.org/reflecting-on-ecocity-times/

Söderqvist, T., Brinkhoff, P., Norberg, T., Rosén, L., Back, P.-E., \& Norrman, J. (2015). Costbenefit analysis as a part of sustainability assessment of remediation alternatives for contaminated land. Journal of Environmental Management, 157. https://doi.org/10.1016/j.jenvman.2015.04.024

Sovacool, B., \& Brown, M. (2010). Twelve Metropolitan Carbon Footprints: A Preliminary Comparative Global Assessment. Energy Policy, 38, 4856-4869. https://doi.org/10.1016/j.enpol.2009.10.001

Stoltz, D., Shafqat, O., Arias, J., \& Lundqvist, P. (2014). On holistic planning in ecocity development: Today and in the past. Energy Procedia, 61, 2192-2195. https://doi.org/10.1016/j.egypro.2014.12.107

Sun, L., Dong, H., Geng, Y., Li, Z., Liu, Z., Fujita, T., ... Fujii, M. (2015). Uncovering driving forces on urban metabolism-A case of Shenyang. Journal of Cleaner Production, 114. https://doi.org/10.1016/j.jclepro.2015.05.053

Tunesi, S. (2010). LCA of local strategies for energy recovery from waste in England, applied to a large municipal flow. Waste Management (New York, N.Y.), 31, 561-571. https://doi.org/10.1016/j.wasman.2010.08.023

Vázquez-Rowe, I., Marvuglia, A., Rege, S., \& Benetto, E. (2014). Applying consequential LCA to support energy policy: Land use change effects of bioenergy production. Science of The Total Environment, 472, 78-89. https://doi.org/10.1016/j.scitotenv.2013.10.097

Wang, L., Templer, R., \& Murphy, R. J. (2012). A Life Cycle Assessment (LCA) comparison of three management options for waste papers: Bioethanol production, recycling and incineration with energy recovery. Bioresource Technology, 120, 89-98. 
https://doi.org/10.1016/j.biortech.2012.05.130

Wang, Z., Huang, K., Yang, S., \& Yu, Y. (2013). An Input-Output Approach to Evaluate the Water Footprint and Virtual Water Trade of Beijing, China. Journal of Cleaner Production, 42, 172179. https://doi.org/10.1016/j.jclepro.2012.11.007

Xi, F., Geng, Y., Chen, X., Zhang, Y., Wang, X., Xue, B., ... Zhu, Q. (2011). Contributing to local policy making on GHG emission reduction through inventorying and attribution: A case study of Shenyang, China. Energy Policy, 39, 5999-6010.

https://doi.org/10.1016/j.enpol.2011.06.063

\section{Appendix A}

Table 1: Petrol and Diesel Car Emission, (El-Sayed et al., 2015).

\begin{tabular}{|c|c|c|c|c|}
\hline Vehicle Type & Engine Size & Size Label & G.CO2 per Km & Liter per $\mathrm{Km}$ \\
\hline \multirow[t]{3}{*}{ Petrol Car } & $<1.41$ & Small & 180.9 & 12.8 \\
\hline & $1.4-2.01$ & Medium & 213.9 & 10.8 \\
\hline & $>2.1$ & Large & 295.8 & 7.8 \\
\hline Average & & & 207.0 & 11.2 \\
\hline \multirow[t]{3}{*}{ Diesel Car } & $<1.71$ & Small & 151.3 & 17.4 \\
\hline & $1.7-2.01$ & Medium & 188.1 & 14.0 \\
\hline & $>2.01$ & Large & 258.0 & 10.2 \\
\hline Average & & & 197.9 & 13.3 \\
\hline
\end{tabular}

Table 2: Taxi and Cairo Cap Emission, (El-Sayed et al., 2015).

\begin{tabular}{|r|r|r|} 
& $\begin{array}{r}\text { Average Passenger } \\
\text { Occupancy }\end{array}$ & G.CO2 Per Passenger Km \\
\hline Taxi & 1.4 & 161.3 \\
\hline Cairo Cap & 1.5 & 175.7 \\
\hline Average & 1.45 & 168.5 \\
\hline
\end{tabular}

Table 3: Vans Emission, (El-Sayed et al., 2015)

\begin{tabular}{|r|r|r|}
\hline Van Fuel & Van size & G.CO2 per Km \\
\hline Petrol & Up to 1.25 tone & 224.4 \\
\hline Diesel & Up to 3.5 tone & 271.8 \\
\hline Average & & 266.1 \\
\hline
\end{tabular}

Table 4: Buses Emission, (El-Sayed et al., 2015) 


\begin{tabular}{|r|r|r|}
\hline Bus Type & Average Passenger Occupancy & G.CO2 per passenger Km \\
\hline Local Bus & 8.9 & 115.8 \\
\hline City bus & 13.5 & 81.8 \\
\hline Average bus & 9.7 & 107.3 \\
\hline
\end{tabular}

Table 5: Motorcycle Emission, (El-Sayed et al., 2015)

\begin{tabular}{|r|r|r|r|r|}
\hline Vehicle Type & Engine Size & Size Label & G.CO2 per Km & Liter per Km \\
\hline Petrol Motorcycle & Up to $125 \mathrm{cc}$ & Small & 72.9 & 31.6 \\
\cline { 2 - 5 } & 125 to $500 \mathrm{cc}$ & Medium & 93.9 & 24.5 \\
\cline { 2 - 5 } & Over $500 \mathrm{cc}$ & Large & 128.6 & 17.9 \\
\hline & Average & & 105.9 & 21.9 \\
\hline
\end{tabular}

Table 6: Railway Emission, (El-Sayed et al., 2015)

\begin{tabular}{|rrr|}
\hline & G.CO2 per Passenger Km & Average Passenger Occupancy \\
\hline Railways & 40.2 & 90 \\
\hline
\end{tabular}

Table 7: CO2 emissions associated with the use of different types of buildings, (El-Sayed et al., 2015)

\begin{tabular}{|c|c|c|}
\hline & Building Type & $\mathrm{G} \mathrm{CO} 2 / \mathrm{m} 2$ \\
\hline \multirow[t]{3}{*}{ Mixed Residential } & Above Average & 30 \\
\hline & Average & 24 \\
\hline & Economic & 20 \\
\hline & Administrative & 67 \\
\hline & Hospital & 88 \\
\hline & Commercial & 164 \\
\hline & Cultural & 35 \\
\hline & Education & 13 \\
\hline & Entertainment & 80 \\
\hline & Religious & 56 \\
\hline & Utilities & 125 \\
\hline
\end{tabular}

Table 8: CO2 emission per factory, (El-Sayed et al., 2015)

\begin{tabular}{|c|c|c|}
\hline Type of Industry & $\begin{array}{r}\text { CO2 emitted per Factory Ton per } \\
\text { Year }\end{array}$ & Number of Factories \\
\hline Agriculture and livestock products & 310.7 & - \\
\hline $\begin{array}{r}\text { Food Processing, beverages and } \\
\text { tobacco }\end{array}$ & 303.4 & - \\
\hline Textiles, garments and leather & 277.7 & - \\
\hline Wood and wooden products & 987.6 & - \\
\hline Paper, printing and publishing & 949.9 & - \\
\hline Chemicals & 5977.8 & - \\
\hline Building materials & 2176.5 & - \\
\hline Metals & 10578.2 & - \\
\hline $\begin{array}{r}\text { Engineering, electrical and } \\
\text { electronics }\end{array}$ & 789.5 & - \\
\hline Manufacturing & 1767.6 & - \\
\hline Repair and maintenance centers & 473.8 & - \\
\hline
\end{tabular}


Table 9: CO2 emission for different land uses, (Source: Chang, T.C., 2000. Determination of greenhouse gases by open-path gas-type FTIR spectroscopy. Food Sci. Agric. Chem.)

\begin{tabular}{|r|r|}
\hline Land Use & Co2 Emission \\
\hline Oxidation Lakes & $1300 \mathrm{mg} / \mathrm{m} 2 * \mathrm{H}$ \\
\hline Agriculture Land & $11.2 \mathrm{Kg} / \mathrm{m} 2$ \\
\hline Forests & $52 \mathrm{gm} / \mathrm{m} 2$ \\
\hline Crusher & $0.5 \mathrm{ton}$ \\
\hline Public Dumps & $220 / \mathrm{m} 2 * \mathrm{H}$ \\
\hline
\end{tabular}




\section{نحو إطار شامل لتقييم التنمية المستدامة في المدن المصرية الجديدة باستخدام نظم

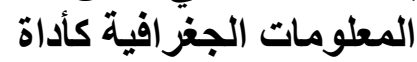

\section{(الملخص:}

أصبحت عملية التتمية الحضرية أكثر صعوبة بسبب التحديات المتزايدة التي تواجه المطورين الحضريين والتتخل

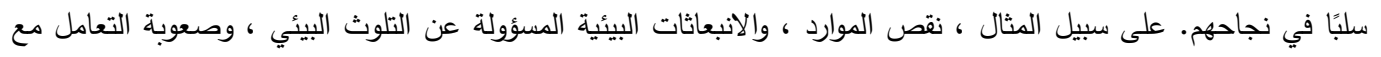

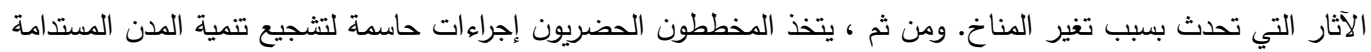

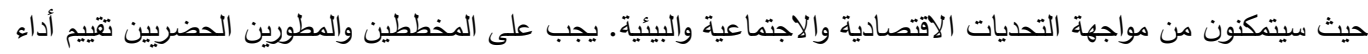

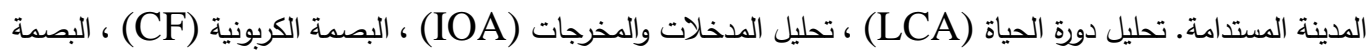

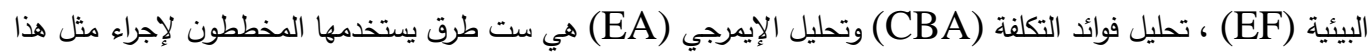

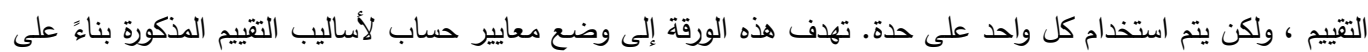

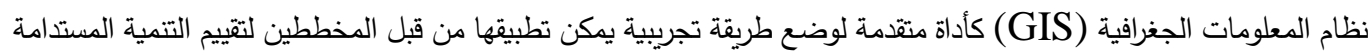

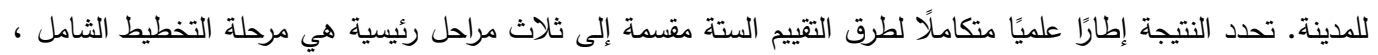

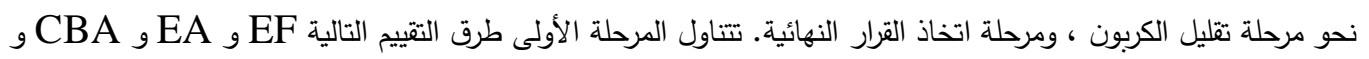

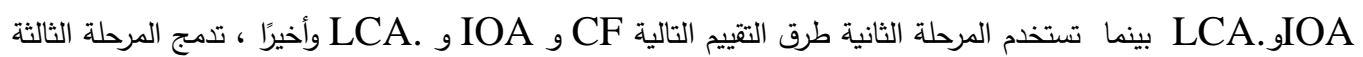

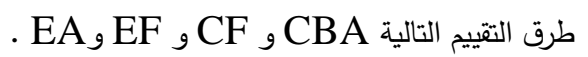

